\title{
雪害対策研究の現況と今後の課題 \\ Preset Status and Prospective Problems of the Study on Measures Against Snowfall Disasters (Outline)
}

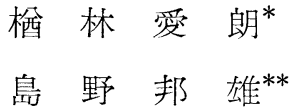

\section{1. はじめに}

38 年 1 月, 日本海測を襲った豪雪により, 山陰, 北 陸，上信越地方などにおいては，人命の損失，鉄道， 道路などの交通の途絶，家屋の倒壊，農林業の被害の ほか，各種産業のまひなど，社会的，経済的に深刻な 打撃をうけた。

かかる状況に対処するため，政府は豪雪非常災害対 策本部を綕理府に設け，災害の応急対策の強力な推進 をはかってきた。

すなわち，現地調査団の派遣を初めとして，主要交 通路線の緊急確保, 災害救助法の適用, 生活必需物質 の優先輸送などによる民生の安定，および特別交付税 の交付や道路除雪費の追加など，緊要な行政措置をと ってきたし，もとょり関係各省庁，公社，地元各府県 においても，それぞれ必要な応急対策が実施された。

しかし，豪雪により今後発生の打それのある災害と しては，3，4月にかけて豪雪地带一带になだれ，融雪 出水, 地すべり, 山くずれならびに農産物に対する冷 害などが考えられる。かかる二次災害に対処するため 恒久対策の一環として，雪害防災に関する科学技術的 な調査, 研究の推進が各方面から要望されている。

從来, 当厅に打いては, 台風, 集中豪雨災害など, 年度途中に発生した緊急新事態に対処して, 特別研究 促進調整費を支出し, 関係省庁研究機関の協力分担の もとに総合的な共同研究を実施し，昭和 35 年度には 東京湾高潮の予警報 $(3,500$ 万円), 昭和 36 年度には 由比地すべり (約 1,250 万円), 天竜川上流域集中豪 雨防災 (約 2,700 万円), 昭和 37 年度には地震予知 方法（約 860 万円）など防災科学技術に関する特別研 究の促進をはかってはた。

今回の豪雪に際しても, 当庁では, 建設, 農林, 防 衛庁などの関係各省庁（試験研究機関をふくむ）抢よ び国鉄からなる「豪雪防災研究連絡会」を設け，豪雪 災害に対する総合的な調査研究の推進のための連絡協 議を行ない，北陸地方等豪雪防琰総合研究課題を設定 し, 特別研究促進調整費 (約 2,300 万円) を支出して,

* 科学技術庁研究調整局総合研究課課長

** 同 調查員
これらの研究を早急に実施することになった。 本研究の各課題は, 現在の雪害対策研究の諸問題点 を一応もうらしていると考えられるので，のちほどそ の概要を紹介することにする。

\section{2. 雪害対策研究の現況}

ひるがえって，雪害対策に関するわが国国立試験研 究機関の現状をみると, 従来, 運輸, 建設, 農林, 北 海道開発などの各省庁研究機関においては，それぞれ の行政目的に応じて，主として防災技術研究に重点を 打いて推進されてきたし，北大，国鉄，電力関係機関 などに抢いても，着実な成果がつみ重㸚られてきた が1)，関連する分野が多いのにもかかわらず，総合的な 研究体制については十分とはいえない状態であった。

大災害が起こると，一元的な行政対策が実施されな かったことが問題となっているが，研究の面に扔いて も，相互連絡抢よび共同研究を緊密にして，効果的な 研究成果をあげることが必要である。

当厅に㧊いては, 昭和 35 年頃から，科学技術に関 する予算の見積方針の調整，研究の実施に関する事務 の総合調整に際して，防災科学技術に関する諸研究を 重点的に推進することに努めてきたが，昭和 37 年研 究調整局の発足以来，関係各省庁と協議して，台風洪 水, 地震津波, 地すべり, 山くずれ，雪害の 4 つの研 究課題を選び，総合研究計画を設定するとともに，各

\section{表 1 雪害防災に関する総合研究}

\begin{tabular}{|c|c|c|c|}
\hline \multicolumn{2}{|c|}{ 研究課題 } & 研 究 機 関 & 研 究 内 容 \\
\hline 1) & $\begin{array}{l}\text { 積雪調 } \\
\text { 査研究 }\end{array}$ & $\begin{array}{l}\text { 北海道開発庁土木試騟 } \\
\text { 所 } \\
\text { 農林省農業技術研究所 } \\
\text { 農林省北陸農業試験場 } \\
\text { 林野序林業試験場 } \\
\text { 運輸省気象研究所 }\end{array}$ & $\begin{array}{l}\text { 凍上および雪害 } \\
\text { 農業気象 } \\
\text { 積雪地帯の作物, } \\
\text { 環境 } \\
\text { 山林と雪害 } \\
\text { 雪および雪の測器 }\end{array}$ \\
\hline 2) & $\begin{array}{l}\text { 雲害対 } \\
\text { 策研究 }\end{array}$ & $\begin{array}{l}\text { 建設省土木研究所 } \\
\text { 林野庁林業試験場 } \\
\text { 農林省北陸農業試験場 } \\
\text { 北海道開発庁土木試験 } \\
\text { 所 }\end{array}$ & $\begin{array}{l}\text { なだれ防止, 除雪 } \\
\text { なだれ防止林 } \\
\text { 冷害, 融雪 } \\
\text { 融雪出水, 凍上凍 } \\
\text { 害 }\end{array}$ \\
\hline
\end{tabular}


省研究課題間の役割と位置を明確にし，研究相互間の バランスのとれた発展を期してきた。（表 1)

しかしながら，各研究機関における雪関係研究者 は，気象庁，農林省，建設省，国鉄をあわせて 30 数 名であり，また雪害防倓研究費については，河川とか 道路とかの公共土木事業にともなう調査費や各研究所 における経常研究費を除いては，表 2 のような額で， 災害の大きさを考えた場合，必ずしも充分であるとは いえない現状である。

\section{表 2 防災科学技術総合研究課題研究費}

(科学技術振興予算)

\begin{tabular}{|c|c|c|c|}
\hline 研 究 課 & 題 & $\begin{array}{l}37 \text { 年 度 } \\
(1,000 \text { 円 })\end{array}$ & $\begin{array}{l}38 \text { 年 度 } \\
(1,000 \text { 円) }\end{array}$ \\
\hline \multicolumn{2}{|c|}{$\begin{array}{l}\text { 台風, 洪水, すべり等 } \\
\text { 防災に関する総合研究 }\end{array}$} & 117,486 & 177,639 \\
\hline \multirow{2}{*}{$\begin{array}{l}\text { 地震，津波，防災 } \\
\text { 雪害，防災 }\end{array}$} & $\prime \prime$ & 22,749 & 324128 \\
\hline & $\prime \prime$ & 8,036 & 17,214 \\
\hline \multirow{5}{*}{\multicolumn{2}{|c|}{$\begin{array}{l}\text { （運輸省気象研究所） } \\
\text { （農林省北陸農業試験場） } \\
\text { （建設省土木研究所） } \\
\text { (北海道開発仃土木試験所） } \\
\text { (科学技術庁研究調整局） }\end{array}$}} & $(1,606)$ & $(1,815)$ \\
\hline & & (188) & (188) \\
\hline & & $(2,340)$ & $(3,016)$ \\
\hline & & $(3,902)$ & $(4,195)$ \\
\hline & & (0) & $(8,000)$ \\
\hline \multicolumn{2}{|l|}{ 計 } & 148,271 & 226,981 \\
\hline
\end{tabular}

注：気象研究所の集中豪雨雪の研究,

37 年度 $23,711,000$ 円, 38 年度 $21,744,000$ 円 は台風等防災研究に計上

\section{3. 北陸地方等豪雪防災特別研究}

本特別研究は, 関係省庁と協議の結果, 研究の対象 を，豪雪ならびに災害の実態の把握と，モデル地域に おける災害諸現象の解明にしぼり，その調査研究の諸 成果がただちに融雪期の二次災害対策に資するようま とめられたものである。

研究分担は表 3 のとおりで, 以下その概要について 述べる。

\section{(1) 航空写真による豪雪調査}

積雪地域の空中写真撮影を行ない，その写真をすみ やかに解読して, 推定積雪量をあらわす等積雪量線, 山腹斜面に生じたきれつの位置, 頻度などを示す地図 を作成し，融雪出水，なだれなどの贸害子測の資料と し，さらに信濃川上流域のモデル地域では特に反覆精 密撮影を行ない，積雪の推移を観测して，災害対策研 究に資するよう計画された。

防衛庁陸海空自衛隊の積極的な協力により，北陸， 山陰の豪雪地带全域約 4 万 $\mathrm{km}^{2}$ にわたる航空写真撮影 が, P 2-V 2 3 機, RF-86 F 4 6 機, T-28 1 機, 立 川の測量大隊，入間の偵察航空隊を動員して実施され た。
表 3 豪雪防災特別研究

\begin{tabular}{|c|c|c|}
\hline 研 究 分 担 & 担 & $\begin{array}{c}\text { 単 位 } \\
(1,000 \text { 円 })\end{array}$ \\
\hline $\begin{array}{l}\text { (1) 空中写真によ } \\
\text { る濠雪調查 }\end{array}$ & $\begin{array}{l}\text { 科学技術庁研究調整局 } \\
\text { (防衛宁自衛隊の協力 } \\
\text { による) } \\
\text { 建設省国土地理院 }\end{array}$ & 12,122 \\
\hline $\begin{array}{l}\text { (2) 融雪災害に関 } \\
\text { する調查研究 } \\
\text { 融雪出水, 地す } \\
\text { ベり,農業災害, } \\
\text { 河川水温低にに } \\
\text { 関する研究 }\end{array}$ & $\begin{array}{l}\text { 建設省土木研究所 } \\
\text { (北陸地建協力) } \\
\text { 科学技術仃研究調整局 } \\
\text { (社団法人河川水温調 } \\
\text { 查会に依託) } \\
\text { 農林省北陸農業試験場 }\end{array}$ & 6,179 \\
\hline $\begin{array}{l}\text { (3) なだれ災害に } \\
\text { 関する調查研究 } \\
\text { なだれ発生機構 } \\
\text { な知なだれ防止 } \\
\text { 林に関する調查 } \\
\text { 研究 }\end{array}$ & $\begin{array}{l}\text { 科学技術庁研究調整局 } \\
\text { (国鉄鉄道技術研究所 } \\
\text { に依䛃) } \\
\text { 農林省林業試験場 }\end{array}$ & 2,136 \\
\hline $\begin{array}{l}\text { (4) 豪雪にともな } \\
\text { う建造物災害調査 }\end{array}$ & $\begin{array}{l}\text { 建設省建築研究所 } \\
\text { (日本建築学会に依託) }\end{array}$ & 967 \\
\hline $\begin{array}{l}\text { (5) 融雪方法に関 } \\
\text { する調查研究 } \\
\text { 農耕地, 市街地 } \\
\text { における融雪方 } \\
\text { 法に関する研究 }\end{array}$ & $\begin{array}{l}\text { 農林省北陸農業試験場 } \\
\text { 科学技術庁研究調整局 } \\
\text { (財団法人積雪研究会 } \\
\text { に依託) }\end{array}$ & 644 \\
\hline $\begin{array}{l}\text { (6) 豪雪防災に関 } \\
\text { する基礎的調査研 } \\
\text { 究 }\end{array}$ & $\begin{array}{l}\text { 科学技術朾研究調整局 } \\
\text { (財団法人防災研究協 } \\
\text { 会に依託) }\end{array}$ & 1,021 \\
\hline 計 & & 23,069 \\
\hline
\end{tabular}

当庁はこれらの縮尺 2 万分の 1 の密着写真を, 各県 の対策本部，建設省，国鉄などに災害対策に関する調 查研究に活用していただくよう配布した。

建設省国土地理院は，この航空写真の解析を担当し たのであるが，積雪量の分布を示す積雪深区分図を， 比較的わずかな，かつ偏在する観測值と，空中写真の 测定，判読だけで大地域を短期間に完成された。新し い積雪調查方法として画期的なものであるといえよ 亏。(図 1)

從来，空中写真は，写真測量によって地形図を作る ことを主目的とし, 最近, 地質判読の分野に利用され つつあるが，条件の悪い積雪期の写真測量と判読の分 野はいまだよく開発されていない。

欧米では，あらかじめ設置された積雪深表示標識を 斜め写真により测定する方法が開発されつつあるが， わが国ではかかる既設標識がなく，また積雪期の写真 と無雪期の写真で大縮尺の等高線図を作成して, その 全体の体積雪差から積雪体積を算出する方法も考えら れなくはないが, 精度, 経費 $\left(7\right.$ 万円 $\left./ \mathrm{km}^{2}\right)$ の点で, 緊急作業としては不向きである。

今回，国土地理院で検討の結果，ステレオ・トープ などにより，河川や池沼の岸高がほとんどない部分で の水涯部の雪面と水面の比高，積雪層のずれやなだれ 


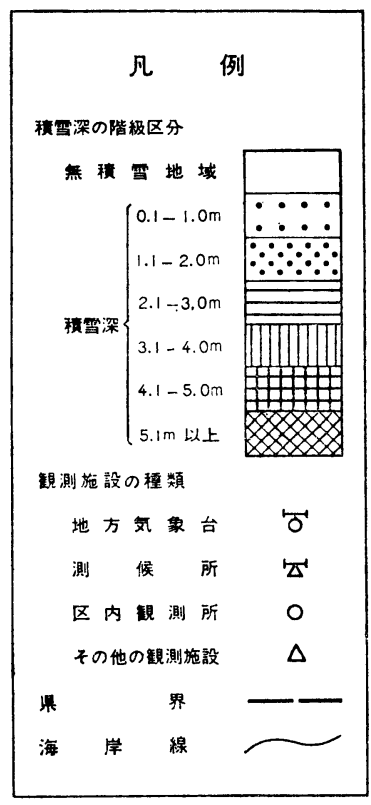

[国土地理院 提供]



図 1 福井地区における積雪区分図（国土地理院提供）
などのために地表面が表われた，その境界面での雪面 と地面との比高, 尾根などで地表面からの植生と雪稜 との間の比高などから，空中写真で積雪深を值接測定 できることがわかったので，5万分の 1 地形図 1 図葉 (約 $400 \mathrm{~km}^{2}$ ) 相当の写真のモデル数 (オーバーラップ 部分をふくむ）約 80〜100 につき 8〜10 モデルをサ ンプル地区として摘出し，この 1 モデル内で $3 \sim 12$ 地 点の積雪深を测定し，等しい積雪深の区域をその測定 值の目やすとして，区内観测所の積雪深実測值（気象 協会の協力による）を測定值の依頼度の基準として写 真上に求め，5万分の 1 地形図上の成果をさらに 20 厅分の 1 図上に編集整理する方法が採用された。

積雪深階級区分による積雪形態は表 4 のような関係 があり，また雪の分布の限界，積雪の表面形態，雪の われ目なだれの発生分布傾向，雪庇の成長度合いとそ の向き，積雪深と雪庇の成長度合いなどによる局地的 卓越風向执よびその強度，新雪なだれと底なだれなど

\section{表 4 積雪深階級亡積雪形態}

\begin{tabular}{|c|c|c|}
\hline $\begin{array}{l}\text { 積雪深階 } \\
\text { 級区分 }\end{array}$ & 相当積雪深 & 積 雪 形 態 \\
\hline 0 & $0 \mathrm{~m}$ & 無雪地带 \\
\hline I & $0 \sim 1 \mathrm{~m}$ & $\begin{array}{l}\text { 地形を白くした程度のもの。 } \\
\text { あるいは視差差がほとんどなく } \\
\text { (0.02 mm以下), 雪の厭さはよ } \\
\text { く注意しないと感じとれない。 }\end{array}$ \\
\hline II & $1.1 \sim 2 \mathrm{~m}$ & 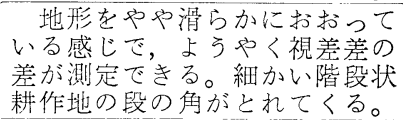 \\
\hline III & $2.1 \sim 3 \mathrm{~m}$ & $\begin{array}{l}\text { 表面形はまだ細かい地形に支 } \\
\text { 配されているが, 細かい段々畑 } \\
\text { 程度のむのは消えてくる。 }\end{array}$ \\
\hline IV & $3.1 \sim 4 \mathrm{~m}$ & 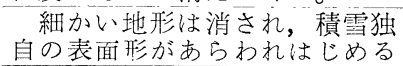 \\
\hline $\mathrm{V}$ & $4.1 \sim 5 \mathrm{~m}$ & $\begin{array}{l}\text { 積雪独自の表面形が多くの面 } \\
\text { 積を占めるようになる。家屋が } \\
\text { 埋ってる。尾根，谷のつなが } \\
\text { り方が無視された等高線であら } \\
\text { われるよるになる。 }\end{array}$ \\
\hline VI & $5.1 \mathrm{~m}$ 以上 & $\begin{array}{r}\text { 地形の細部は全く消され，積 } \\
\text { 雪独自の表面形が全く優先す场 }\end{array}$ \\
\hline
\end{tabular}


が判読できることがわかった。

今後，写真撮影方法および時期，視差差の測定の問 題, 精度向上のための積雪前の準備工作など, 検討す べき課題は大変多いが，この積雪区分図の完成によっ て融雪出水に対する積雪量の計算や，なだれ危険区域 の想定などに貴重な資料が提供できるようになった。

\section{(2) 融雪災害に関する調查研究}

a) 融雪出水に関する調査研究現在建設省では 信濃川支流魚野川上流域で, ラジオ・アイソトープと 無線を利用した融雪量の測定と, 流速, 水位観測とに よる融雪出水に関する基礎研究を実施中であるが，従 来北陸地建で調查研究中であった佐梨川流域をもふく めて，信濃川流域の水位観測所などに風速，日射，温 湿度計など気候観測計器を充実し, 河川の融雪出水機 構を総合的に解明して洪水予報および流量の長期的予 報などに資するよう調査研究が行なわれた。

また，九頭竜川支流の滝波川流域においては，河川 水温調查会が電力関係研究者などの協力をえて, スノ 一サーベイや気候観測機器による連続観測により, 融 雪量ならびに融雪機構の調査を実施し，また流量，水 位の依託観測の資料をあわせ，融雪期における河川流 量と気温などの関係を求める研究を行なった。

これら両河川の融雪出水状況の資料を総合して，北 陸地域に打ける各河川の融雪出水対策の資料とするこ とができる。

b）融雪にともなう地すべりに関する研究従来 東北，北陸地方に発生するいわゆる第 3 紀層地すべり の約 $65 \%$ は融雪時に起こっており, 特に豪雪年の融 雪期にはその発生率はこれを上まわる数字を示してい る。

豪雪地带にモデル地を選び，この地域で融雪量を測 定し，これと傾斜計，伸縮計の測定による地すべり移 動速度との関連性を見出すとともに, 融雪水の地下浸 透による土の含水比の変化, それに付随して生じる地 すべり土塊の軟弱化程度を, 土質, サウンディング試 験などにより調査し，融雪と地すべり速度との関連な どその発生機構を解明し，豪雪下における地すべりの 予知と防止対策に資するものである。

モデル地域として選定した新潟県杤尾市北荷頃町 は，昨年融雪期に約 $13 \mathrm{ha}$ の地域が地すべりを起こし， 県で排水など緊急対策事業を実施したのであるが，現 在再び約 20 ha にわたり地すべり移動を生じ, 今回の 豪雪にともなう地すべりの誘発, 活発化が憂慮されて いる地域である。

c）融雪にともなう農業災害，河川水温の低下に関 する研究豪雪ならびに融雪期の遅延は, 農作物に 病害虫による被害や冷害など種々の悪影響をおよぼし
ている。

農林省北陸農試では，高田および近傍の明治闻場を モデル試験地として病害虫の消長過程を明らかにし, また河川水温調査会では, 従来も冷害の多かった黒 部, 压川, 阿賀野, 荒川, 信濃の 6 河川について水温 を観測しデータの収集を行なうなど，行政指導，冷害 防止対策などの基礎を確立するための調査研究が早急 に行なわれた。

（3）なだれ災害に関する調查研究

a)なだれ発生機構に関する調査研究今回の豪 雪により，多方面で融雪期のなだれ災害の発生が予想 され, 出水とともに早急な予知方法の確立が要望され ている。

国鉄鉄道技術研究所では，すでに人工なだれなどい くつかの実験を通じて, その発生機構などに関する研 究の成果をあげている。今回の豪雪にもとづく,なだ れ発生の諸要因を調查研究するため塩沢の雪害防止実 験所を基地としてなだれに関する新しい予知方法につ いて研究が行なわれた。すなわち、ヘリコプターによ り多種の斜面積雪状態, なだれ発生過程の観測をつづ け，基地における気象観測，積雪面上の熱収支測定な どの資料と関連して，いろいろな方位および被覆状態 の斜面におけるなな゙れ発生状態と気象積雪状態の関係 を明らかにする研究がつつけりれなな゙れ発生機構お よび予知方法決定のための貴重な成果が得られた。

b）なだれ防止林に関す調査研究農林省林業試 験場と十日町試験地と共同して, 新潟県中部森林基本 計画区をモデル地域として，なだれ防止林の現状なら びに効果などに関する現地調査が行なわれた。

\section{（4）豪雪にと䣊なう建造物災害調査}

雪質, 含水率の変化は雪荷重に相当な変化を与え る。建物の被害状況, 積雪荷重などの実態を調査し, 早急に行政指導上ならびに今後の対策研究上必要な資 料を求めるばならない。建設省建築研究所が主体とな り, 日本建築学会の協力のもとに, 多方面の資料の収 集が行なわれた。

\section{(5) 融雪方法に関する調査研究}

ヘリコプターによる農耕地などの大規模融雪方法お よび新潟県長岡市において一部道路, 屋根面などにお いて実施中の地下水を利用したパイプ配管による融雪 方法については，すでに北陸農業試駼場および積雪研 究会において基礎的な実験が行なわれている。農耕地 および市街地において実用的規模で実施された本試験 研究の成果は, 今回のいわゆる里雪型の豪雪に対して きわめて効果が多いものと期待される。

\section{（6）豪雪防災に関する基礎的調査研究}

今回の豪雪は，里雪という特性をもち，比較的べた 
雪の性質をもっていて，北海道のこな雪と相違してお り，また降雪の分布にも特異の性質をもっているので あるが，従来北陸地方に抢いては総合的な基礎的調查 がほとんど行なわれていなかった。

防災研究協会では, 京都大学防災研究所などの協力 によって, 豪雪機構, 雪質, 積雪分布, 融雪過程など の現象を究明するため，福井，富山，新潟県を中心と する現地調査を行ない, ついて誘発されるなだれ, 融 雪洪水, 山くずれ, 地すべりなどの予知防止対策を学 術的に研究することになった。

雪質の分布調查からの降雪機構の解明, 片具川上流 域モデル地域とするなだれの実態調査, 近畿地建福井 工事事務所，中・高等学校などの協力による九頭竜川 全流域の融雪出水に関する水文学的調查, 新潟県東頸 城郡松之山地区を中心とする融雪地すべりの土質力学 的, 地球物理学的観点からの発生機構の解明などの諸 研究は，その成果に期される点が多い。

\section{4. 雪害対策研究の今後の課題}

当庁では災害に対する科学的な対策技術，すなわち 災害における自然現象と社会現象との相関関係を自然 科学的に究明する科学，ならびにこの科学を基礎とし て発展すべき技術，すなわち災害を防止または最小限 に食い止める技術を防災科学技術と考え，これらを具 体的かつ効果的に実施するための中心母体として，38 年度より当庁付属機関として, 国立防災科学技術セン ターが発足せしめた。

本センターは, 防災科学技術に関し, 試験研究用の
施設抢よび設備を関係各省庁の共用に供し, 流動研究 員を派遣し，内外資料の収集整備を行なうなど，防災 科学技術の総合的推進に関する中核的機構となるもの であって，雪害防災に関しても，本センターの雪害研 究室は, 関係研究機関と総合研究体制を確立し, 総合 的な研究促進の場となり, また災害の地域性と時限の 問題を考慮して，地域的，共同的な総合調查研究を実 施する場となり，あるいは共通的な試験研究を実施す る場となるよう期待されているものである。

研究の基礎となる観測, 測定機器の整備, 研究者の 待遇, 環境の改善など 今後とも推進すべき課題は多 w。

今回の豪雪災害は, 死者 197 人, 負傷者 320 人を 生じ直接的な農林水産物, 交通機関などの被害をはじ め, 間接的な産業経済上の損害は数百億円にのぼると 推定され，二次災害の危機もせまりつつある。

尊い生命を守り，またここれだけの富を新たに生産 することがどんなに大変であるかを思えば，災害の予 防あるいは防止対策の基礎となるべき雪害防災の科学 技術的研究の促進に大きな努力をはらっても, 日本経 済全体として引きあうであろうし，その結果は，また

「裹日本」といわれる豪雪地域の後進性の改善に寄与 するところが大であろう。

\section{参 考 交 献}

1）雪害（防雪，除雪）関係文献抄録，雪害に関す る研究調查目録抄 (経済企画庁総合開発局 38.2 家雪刘策審議会資料)

(土木学会誌 Vol. 48, No. 5 より再録)

\section{口雪害対策に対する航空写真の利用方法に関するシンポジュウム}

$\boldsymbol{\nabla} 3$ 月 6 日, 第 10 回常務理事 会が，港区麻布新竜土町の竜土軒 で開かれ，3月 7 日の “雪害対策 に対する航空写真の利用方法に関 するシンポシュウム”の議事運営 について審議された。

出席者 中野, 笠松, 真塩, 小 泉, 中島, 丸安各理事, 事務 局大島, 西村

当日の司会は丸安理事と中野理 事で担当。講演終了後の討論の進 め方，その内容又記録のとり方， 招待者, 新聞記者の取り扱い方等 について種々検討をおこなった。
V3月 7 日“シンポジュウム” の集りが東大生研の中央会議室で 午後 1 時半よりおこなわれ，最初 に講演，つづいて参加者の自由討 議が活発にかわされた。

1. 豪雪の判読研究

高崎正義・五百沢智也

2. 写真判読による ナダレの测定篠 邦彦

3. 航空写真による ナダレの調査荘田幹夫

防衛庁林部員, 気象庁林防災気 象官よりそれぞれの立場で今回の 豪雪についての説明があった。

参加者は約 150 名, 活発な意見 に熱心な討議がおこなわれた。

\section{フイルム研究グループの集リ}

3 月 9 日第 1 部会のフイルム 研究グループの集りが東大生研究 会議室でおこなわれた。

出席者, 武田, 鯨井, 鍛治, 大 賀，平塚，大管

1. 3 月 1 杯で各会社で所定場 所の撮影を高度抢よびシャッター 速度をかえて抗こない，フイルム の耐電性の影響，気温等の影響を しらべる。

2. 泡像的にはラマトチャート を入れる等の実作業の進め方につ いての細則を打合せた。

3. 今までフイルムの研究実験 を実施させていた日本林業協会へ は学会より便宜, 依頼の公文書を 作成する。 